\title{
Combining Ability for Yield and Yield Attributes Characters in Greengram (Vigna radiata L. Wilczek)
}

\author{
S.M. Surashe", D.K. Patil and V.K. Gite \\ Agricultural Research Station Badnapur, Vasantrao Naik Marathwada, Krishi Vidyapeeth, \\ Parbhani- 431 402, Maharashtra, India \\ *Corresponding author
}

\author{
A B S T R A C T
}

Five lines were crossed with four testers in Line $\times$ Tester fashion to estimate the combining ability for yield and yield attributing traits in greengram. Analysis of variance

Keywords

SCA, GCA and Greengram.

\section{Article Info}

Accepted:

26 September 2017

Available Online:

10 November 2017 revealed significant differences among genotypes, crosses, lines, testers and line $\times$ tester interactions for most of the traits. Preponderance of non-additive gene effects was realized from higher values of specific combining ability compared to general combining ability and ratio of variances of SCA to GCA except for day to maturity. Parents' viz., IPM 2-3, ML 1299, ML and 2037 were considered as superior parents as they recorded high per se performance with positive significant effects for seed yield per plant and other yield contributing traits. Cross combinations viz., BM 2003-2 x IPM 2-3, VAIBHAV x IPM 409-4, BM 4 x MH 2-15, BM 4 x PUSA 0612, VAIBHAV x ML 1299, AKM 4 x MH 215, BM 2002-1 x ML 818 and AKM 4 x IPM 409-4 were found to be good specific combinations for seed yield per plant and other desirable traits. These cross combinations could be utilized for further amelioration of seed yield in greengram.

\section{Introduction}

Greengram [Vigna radiata (L.) Wilczek], is an economically important short duration grain legume characterized by relatively more palatable, nutritive, cheap source of high quality and easily digestible protein, nonflatulent than other pulses and constitute an important source of cereal based diets in Asia (Kamleshwar et al., 2014). In-spite of high demand, the yield of greengram worldwide is very low (384 kg/ha) and limited success has been achieved so far in augmenting its yield. To enhance the present yield levels, it is essential a systemic varietal improvement through hybridization and exploitation of generated variability through recombination breeding. To breed a genotype with high yielding potential, the information on the genetic mechanism controlling various traits in the material being handled, is a prerequisite. The estimates of combining ability along with per se performance of genotypes in a crop improvement program have a direct bearing upon the choice of breeding methodology to be followed and to identify the parent and crosses (Khattak et al., 2004), which could be exploited for future breeding programme. In literature, both additive and non-additive genetic systems, controlling seed yield and yield-relating traits in greengram, have been reported (Barad et al., 2008, 
Marappa, 2008; Sathya and Jayamani, 2011; Sujatha and Kajjidoni, 2013 and Suresh, 2014). However, the major part of genetic variation for yield and its components was conditioned due to higher magnitude of nonadditive genetic effects (Marappa, 2008; Sathya and Jayamani, 2011; Sujatha and Kajjidoni, 2013 and Suresh, 2014). Seed yield and several yield contributing characters lack stability due to strong environmental influence, suggesting the need for breeding for specific environment. Therefore, the present investigation was planned and executed to assess the nature of gene action involved and combining ability of parental genotypes for different characters utilizing Line $\times$ Tester mating design (Kempthorne, 1957) for evolving productive varieties in greengram.

\section{Materials and Methods}

Five lines BM 4, BM 2002-1, BM 2003-2, AKM 4, and VAIBHAV were crossed with seven tester IPM 409-4, ML 1299, MH 2-15, IPM 2-3, ML 2037, ML 818, and PUSA 0612 in Line $\mathrm{X}$ tester fashion at Agricultural Research station, Badnapur. College of Agriculture Badnapur, Maharastra. All the genotypes (twelve parent and $35 \mathrm{~F}_{1}$ 's) were evaluated in Randomized Block Design with two replication during summer, 2014. Each genotype was grown in one row of four meter length with a spacing of $30 \mathrm{~cm}$ between row and $15 \mathrm{~cm}$ between plants. Recommended agronomic and plant protection package of practice were followed to raise healthy crop. Data were recorded on five randomly selected competitive plants in each genotype and replication. Mean value on per plant basis were recorded for the characters, viz., plant height, number of cluster per plant, number of pod per cluster, number of pod per plant, number of seed per pod, pod length, hundred seed weight, seed yield per plant, protein content and the micro-Kjeldahl ' $N$ ' procedure was used for the determination of nitrogen and crude protein was estimated by multiplying the nitrogen content by a factor of 6.25. However, data on day to $50 \%$ flowering and maturity were recorded on plot basis. The mean data was analysed to compute combining ability effect and their variances according to Kempthorne (1957).

\section{Results and Discussion}

Analysis of variance along with the estimates of gca and sca variance their ratio for eleven character is shown in table 1 . The annova showed highly significant differences for majority of character, indicating the presence of sufficient variability in experimental material. The variance due to crosses was highly significant for all the traits which indicated the diverse nature of selected parent for majority of the character. Partitioning of variance among the hybrid revealed that the mean square due to line showed highly significant differences for plant height, pod length and 100 seed weight, which indicated the presence of sufficient variability for these three characters. Significant variance is due to tester for plant height and protein content. The significant variance due to line $\mathrm{x}$ tester interaction for all the traits excepting that of plant height showed its existence among the tester and hybrid population respectively for these eleven traits. This indicated the presence of significant differences between males and females.

Based on the study per se performance of parents and estimates of gca effect Among female parents, BM 4 exhibited significant GCA effects for plant height, number of pods per cluster and number of pods per plant. The line BM 2002-1 exhibited significant GCA effects for days to maturity, number of seed per pod, pod length and hundred seed weight, while BM 2003-2 was good general combiner for day to $50 \%$ flowering, day to maturity, 
number of clusters per plant, pod length and hundred seed weight, while VAIBHAV was good general combiner for plant height, number of pod per plant and protein per cent.

Out of seven males, IPM 409-4 was a good general combiner for number of pod per cluster, number of pods per plant, where as ML 1299 was found good general combiner for Days to maturity, number of pod per plant and seed yield per plant. The tester MH 2-15 was found good general combiner for day to $50 \%$ flowering, days to maturity and number of pod per cluster.

Whereas IPM 2-3 was a good general combiner for day to $50 \%$ flowering, day to maturity, number of cluster per plant, number of pod per cluster, number of pod per plant, pod length, seed yield per plant and protein per cent, whereas ML 2037 was a good general combiner for day to $50 \%$ flowering, day to maturity, number of cluster per plant, pod length, hundred seed weight and protein per cent, whereas ML 818 also good general combiner for day to maturity and hundred seed weight, whereas PUSA 0612 was a good general combiner for plant height, and protein per cent (Table 2). Similar results were reported by Reddy and Sreeramulu (1982), Choudhary (1986), Halkunde et al., (1996), Dasgupta et al., (1998), Jahagirdar (2001), Aher et al., (1999), Singh (2005), Barad et al., (2008), Patil et al., (2011).

The cross combination BM 2003-2 X IPM 2-3 (5.63) recorded highest significant desirable SCA effect for grain yield per plant. Similar result has also been reported by Barad et al., (2008), Patil et al., (2011).

The cross combination BM 4 x PUSA 0612 (7.42) recorded highest significant desirable SCA effect for number of pods per plant. This result is in agreement with the finding of Ahuja (1980), Shanthi priya et al., (2012).
The highest significant negative desirable SCA effect was observed for days to $50 \%$ flowering in AKM 4 x ML 2037 (-3.30) these finding are in agreement with earlier report made by Deshmukh and Manjare (1980) and Jahagirdar (2001).

The highest significant negative desirable SCA effect was observed for days to maturity in BM 2003-2 x ML 2037 (-2.91) similar result were also reported by Jahagirdar (2001).

For plant height in BM 2003-2 x ML 2037 (5.84) was observed highest significant desirable SCA effect. This result was in agreement with the findings of Manjare (1976), Shanthi priya et al., (2012)

The cross combination BM 2002-1 x IPM 409-4 (2.91) had recorded highest significant desirable SCA effect for number of clusters per plant. Similar results were also reported by Manjare (1976), Shanthi priya et al., (2012).

For number of pods per cluster in $\mathrm{BM} 4 \mathrm{x} \mathrm{MH}$ 2-15 (1.94) was revealed highest significant desirable SCA effect. This result was in agreement with the finding of Shanthi priya $e t$ al., (2012).

The cross combination AKM 4 x ML 1299 (1.53) observed highest significant desirable SCA effect for number of seed per pod (Table $3)$. These results are in confirmation with the previous work done by Jahagirdar (2001), and Singh and Dikshit (2003).

The hybrid combination BM 2003-2 x IPM 409-4 (1.83) recorded highest significant desirable SCA effect for pod length.

Similar result has also been reported by Yadav and Lavanya Roopa (2011). 
Table.1 Analysis of variance of line X tester with respect to eleven characters in Mungbean [Vigna radiata (L.) Wilczek]

\begin{tabular}{|c|c|c|c|c|c|c|c|c|c|c|c|c|}
\hline Sorce of variability & d.f & $\begin{array}{c}\text { Days to } \\
\mathbf{5 0 \%} \\
\text { flowering }\end{array}$ & $\begin{array}{c}\text { Days to } \\
\text { maturity }\end{array}$ & $\begin{array}{l}\text { Plant } \\
\text { height }\end{array}$ & $\begin{array}{c}\text { No. of } \\
\text { clusters } \\
\text { per plant }\end{array}$ & $\begin{array}{c}\text { No. of } \\
\text { pods per } \\
\text { cluster }\end{array}$ & $\begin{array}{c}\text { No. of } \\
\text { pods per } \\
\text { plant }\end{array}$ & $\begin{array}{c}\text { No. of } \\
\text { seeds } \\
\text { per pod }\end{array}$ & $\begin{array}{c}\text { Pod } \\
\text { length }\end{array}$ & $\begin{array}{c}\text { 100-seed } \\
\text { weight }\end{array}$ & $\begin{array}{c}\text { yield per } \\
\text { plant }\end{array}$ & Protein \\
\hline Replication & 1 & 0.51 & 0.01 & 1.06 & 0.58 & 0.25 & 1.82 & 0.02 & 0.04 & 0.02 & 0.82 & 0.01 \\
\hline Crosses & 34 & $8.15 * *$ & $34.41 * *$ & $56.78 * *$ & $5.67 * *$ & $2.54 * *$ & $47.10 * *$ & $1.46 * *$ & $3.41 * *$ & $0.79 * *$ & $9.64 * *$ & $2.86 * *$ \\
\hline Lines & 4 & 11.66 & 28.76 & $121.47 *$ & 6.47 & 5.09 & 95.94 & 1.91 & $13.18 * *$ & $3.88 * *$ & 12.54 & 4.36 \\
\hline Testers & 6 & $15.49 *$ & $133.43 * *$ & $120.41 * *$ & 3.29 & 0.75 & 53.57 & 1.63 & 1.65 & 0.46 & 5.95 & $5.62 *$ \\
\hline Females x Males (L x T) & 24 & $5.73 * *$ & $10.60 * *$ & 30.08 & $6.14 * *$ & $2.48 * *$ & $37.35 * *$ & $1.34 * *$ & $2.22 * *$ & $0.35^{* *}$ & $10.08 * *$ & $1.92 * *$ \\
\hline Error & 34 & 0.86 & 0.44 & 2.60 & 0.16 & 0.07 & 0.49 & 0.22 & 0.02 & 0.02 & 0.96 & 0.09 \\
\hline
\end{tabular}

Table.2 Estimation of general combining ability with respect to eleven characters in Mungbean (Vigna radiata L. Wilczek)

\begin{tabular}{|c|c|c|c|c|c|c|c|c|c|c|c|}
\hline Genotypes & $\begin{array}{c}\text { Days to } \\
50 \% \\
\text { flowering }\end{array}$ & $\begin{array}{l}\text { Days to } \\
\text { maturity }\end{array}$ & $\begin{array}{c}\text { Plant } \\
\text { height }\end{array}$ & $\begin{array}{c}\text { No. of } \\
\text { clusters } \\
\text { per plant }\end{array}$ & $\begin{array}{c}\text { No. of } \\
\text { pods per } \\
\text { cluster }\end{array}$ & $\begin{array}{c}\text { No. of } \\
\text { pods per } \\
\text { plant }\end{array}$ & $\begin{array}{c}\text { No. of } \\
\text { seeds per } \\
\text { pod }\end{array}$ & Pod length & $\begin{array}{c}100 \text { seed } \\
\text { weight }\end{array}$ & $\begin{array}{c}\text { Seed yield } \\
\text { per plant }\end{array}$ & $\begin{array}{l}\text { Protein } \\
\text { per cent }\end{array}$ \\
\hline \multicolumn{12}{|l|}{ Testers } \\
\hline IPM 409-4 & $2.44 * *$ & $7.80 * *$ & 0.86 & -0.07 & $0.21 *$ & $1.56^{* *}$ & $-0.89 * *$ & 0.03 & $-0.14^{*}$ & -0.16 & $-0.42 * *$ \\
\hline ML 1299 & 0.44 & $-2.60 * *$ & $-1.34 *$ & -0.12 & -0.01 & $3.15^{* *}$ & 0.17 & $-0.27 * *$ & $-0.12 *$ & $0.60 *$ & -0.03 \\
\hline MH 2-15 & $-1.25 * *$ & $-0.50 *$ & $-2.66^{* *}$ & $-0.91 * *$ & $0.29 * *$ & 0.43 & 0.26 & $-0.16 * *$ & 0.00 & 0.36 & $-1.17 * *$ \\
\hline IPM 2-3 & $-0.65^{*}$ & $-2.80 * *$ & $-2.02 * *$ & $0.43 * *$ & $0.25^{* *}$ & $1.55^{* *}$ & -0.03 & $0.38 * *$ & 0.04 & $0.90^{* *}$ & $0.50 * *$ \\
\hline ML 2037 & $-1.05 * *$ & $-0.80 * *$ & -0.83 & $0.95 * *$ & $-0.19 *$ & $-1.71 * *$ & 0.20 & $0.64 * *$ & $0.20 * *$ & -0.22 & $1.10 * *$ \\
\hline ML 818 & 0.04 & $-1.80 * *$ & $-1.43 * *$ & -0.16 & 0.07 & $-1.52 * *$ & 0.13 & -0.06 & $0.33 * *$ & -0.01 & $-0.40 * *$ \\
\hline PUSA 0612 & 0.04 & $0.70 * *$ & $7.46^{* *}$ & -0.12 & $-0.63 * *$ & $-3.44 * *$ & 0.14 & $-0.56 * *$ & $-0.29 * *$ & $-1.47 * *$ & $0.43 * *$ \\
\hline S.E \pm & 0.28 & 0.20 & 0.51 & 0.11 & 0.08 & 0.21 & 0.15 & 0.05 & 0.05 & 0.29 & 0.08 \\
\hline C.D. at $5 \%$ & 0.57 & 0.41 & 1.04 & 0.23 & 0.17 & 0.43 & 0.31 & 0.11 & 0.12 & 0.59 & 0.17 \\
\hline C.D. at $1 \%$ & 0.76 & 0.55 & 1.39 & 0.31 & 0.23 & 0.58 & 0.42 & 0.15 & 0.16 & 0.80 & 0.22 \\
\hline \multicolumn{12}{|l|}{ Lines } \\
\hline BM 4 & $1.47 * *$ & $2.08 * *$ & $3.22 * *$ & $-0.85 * *$ & $0.83 * *$ & $1.82 * *$ & -0.01 & $-0.59 * *$ & $-0.43 * *$ & 0.06 & $-0.30 * *$ \\
\hline BM 2002-1 & -0.10 & $-1.84 * *$ & $-3.43 * *$ & -0.02 & $-0.52 * *$ & $-3.19 * *$ & $0.61 * *$ & $1.13 * *$ & $0.44 * *$ & $-1.18 * *$ & $-0.32^{* *}$ \\
\hline BM 2003-2 & $-0.88 * *$ & $-0.48 * *$ & $-1.68 * *$ & $1.03 * *$ & $-0.563 * *$ & $-2.14 * *$ & -0.13 & $0.82 * *$ & $0.59 * *$ & 0.26 & $-0.41 * *$ \\
\hline AKM 4 & $-0.60 *$ & $0.44 *$ & $-1.03 *$ & 0.04 & $0.39 * *$ & $3.00 * *$ & $-0.39 * *$ & $-1.18 * *$ & $-0.61 * *$ & $1.36 * *$ & 0.11 \\
\hline VAIBHAV & 0.11 & -0.20 & $2.93 * *$ & $-0.20 *$ & -0.13 & $0.51 * *$ & -0.07 & $-0.17 * *$ & 0.00 & $-0.51 *$ & $0.92 * *$ \\
\hline S.E \pm & 0.23 & 0.17 & 0.43 & 0.09 & 0.07 & 0.18 & 0.13 & 0.04 & 0.05 & 0.24 & 0.07 \\
\hline C.D. at $5 \%$ & 0.48 & 0.34 & 0.88 & 0.20 & 0.14 & 0.37 & 0.26 & 0.09 & 0.10 & 0.50 & 0.14 \\
\hline C.D. at $1 \%$ & 0.64 & 0.46 & 1.18 & 0.26 & 0.1985 & 0.4981 & 0.35 & 0.13 & 0.13 & 0.67 & 0.19 \\
\hline
\end{tabular}

$*$ and $* *$ indicates significance at 5 and 1 per cent level respectively. 
Table.3 Estimates of specific combining ability with respect to 11 characters in Mungbean (Vigna radiata L. Wilczek)

\begin{tabular}{|c|c|c|c|c|c|c|c|c|c|c|c|c|}
\hline $\begin{array}{l}\text { Sr. } \\
\text { No. }\end{array}$ & Crosses & $\begin{array}{c}\text { Days to } 50 \% \\
\text { flowering }\end{array}$ & $\begin{array}{c}\text { Days to } \\
\text { maturity }\end{array}$ & $\begin{array}{l}\text { Plant } \\
\text { height }\end{array}$ & $\begin{array}{c}\text { Cluster/ } \\
\text { plant }\end{array}$ & $\begin{array}{c}\text { No. of pods/ } \\
\text { cluster }\end{array}$ & $\begin{array}{c}\text { No. of pods/ } \\
\text { plant }\end{array}$ & $\begin{array}{c}\text { No. of } \\
\text { seed/ pod }\end{array}$ & Pod length & $\begin{array}{c}100 \text { seed } \\
\text { weight }\end{array}$ & Yield/plant & Protein \\
\hline 1 & BM 4 X IPM 409-4 & 1.12 & $-2.08 * *$ & 0.78 & $-1.45 * *$ & $-2.03 * *$ & $-7.08 * *$ & $1.02 * *$ & $-1.49 * *$ & -0.02 & $-2.77 * *$ & 0.29 \\
\hline 2 & BM 4 X ML 1299 & -0.37 & 0.31 & -2.00 & $0.69 *$ & $-0.85 * *$ & $-3.12 * *$ & -0.34 & $0.26^{*}$ & 0.02 & $-1.90 * *$ & $-1.29 * *$ \\
\hline 3 & BM 4 X MH 2-15 & 0.82 & $-1.28 * *$ & $2.91 *$ & 0.43 & $1.94 * *$ & $6.69 * *$ & -0.43 & 0.00 & -0.18 & $2.50 * *$ & -0.10 \\
\hline 4 & BM 4 X IPM 2-3 & -0.77 & $2.01 * *$ & $2.47 *$ & -0.05 & -0.02 & $2.02 * *$ & -0.03 & $1.65 * *$ & -0.02 & 0.69 & $-0.68 * *$ \\
\hline 5 & BM 4 X ML 2037 & 0.12 & $4.51 * *$ & 1.18 & $-0.72 * *$ & $1.93 * *$ & $-1.35 * *$ & -0.27 & $-0.59 * *$ & -0.05 & -0.20 & $-0.58 * *$ \\
\hline 6 & BM 4 X ML 818 & -0.47 & $-0.98 *$ & 0.53 & $-1.26 * *$ & $-0.64 * *$ & $-4.59 * *$ & 0.09 & -0.24 & 0.16 & -0.54 & $1.37 * *$ \\
\hline 7 & BM 4 X PUSA 0612 & -0.47 & $-2.48 * *$ & $-5.91 * *$ & $2.34 * *$ & -0.33 & $7.42 * *$ & -0.01 & $0.40 * *$ & 0.10 & $2.23 * *$ & $0.99 * *$ \\
\hline 8 & BM 2002-1 X IPM 409-4 & $2.70 * *$ & $2.84 * *$ & 1.44 & $2.91 * *$ & $-0.57 * *$ & $-1.31 *$ & $1.35^{* *}$ & $0.92 * *$ & -0.20 & $-1.43^{*}$ & $-0.98 * *$ \\
\hline 9 & BM 2002-1 X ML 1299 & 0.20 & 0.74 & -1.74 & $-2.03 * *$ & $0.70 * *$ & 0.79 & $-1.07 * *$ & $-0.84 * *$ & $0.32 *$ & 0.08 & $0.78^{* *}$ \\
\hline 10 & BM 2002-1 X MH 2-15 & -1.10 & -0.85 & -0.67 & 0.35 & $-1.10 * *$ & $-6.23 * *$ & -0.56 & $0.72 * *$ & -0.01 & -0.62 & $-1.12 * *$ \\
\hline 11 & BM 2002-1 X IPM 2-3 & -1.20 & $0.94 *$ & 0.63 & $-1.93 * *$ & $-0.66^{*}$ & $-2.30 * *$ & 0.29 & $-0.57 * *$ & 0.06 & -0.45 & $1.42 * *$ \\
\hline 12 & BM 2002-1 XML 2037 & 0.70 & $-1.05^{*}$ & -1.05 & $0.793 * *$ & $-0.81 * *$ & 0.71 & 0.55 & $0.65 * *$ & $0.44 * *$ & 0.77 & $-0.56 * *$ \\
\hline 13 & BM 2002-1 X ML 818 & 0.10 & -0.05 & $2.59 *$ & -0.39 & 1.81 & $5.92 * *$ & -0.03 & $-1.12 * *$ & -0.26 & $1.91 * *$ & 0.19 \\
\hline 14 & BM 2002xPUSA0612 & $-1.40 *$ & $-2.55 * *$ & -1.20 & 0.31 & $0.62 * *$ & $2.39 * *$ & -0.54 & 0.24 & $-0.35^{*}$ & -0.26 & 0.26 \\
\hline 15 & BM 2003-2 XIPM 409-4 & $-2.51 * *$ & 0.48 & $-2.75^{*}$ & $-1.84 * *$ & $1.46 * *$ & $2.43 * *$ & $-0.90 *$ & $1.83 * *$ & 0.15 & -0.30 & $0.89 * *$ \\
\hline 16 & BM 2003-2 X ML 1299 & -0.01 & $-1.11 *$ & $-5.79 * *$ & $-0.69 *$ & -0.15 & 0.94 & -0.52 & $-0.51 * *$ & -0.01 & -0.99 & -0.21 \\
\hline 17 & BM 2003-2 X MH 2-15 & $-2.81 * *$ & $5.28 * *$ & 1.07 & $-2.70 * *$ & $-1.31 * *$ & $-3.03 * *$ & 0.53 & $-1.37 * *$ & -0.15 & $-3.09 * *$ & $0.65^{* *}$ \\
\hline 18 & BM 2003-2 X IPM 2-3 & $2.08 * *$ & $-1.91 * *$ & -0.91 & $1.95 * *$ & $1.52 * *$ & $6.24 * *$ & $0.98 * *$ & $-0.86 * *$ & $0.45 * *$ & $5.63 * *$ & $-0.52 * *$ \\
\hline 19 & BM 2003-2 X ML 2037 & 0.98 & $-2.91 * *$ & $5.84 * *$ & $2.83 * *$ & $-1.02 * *$ & $-2.33 * *$ & -0.18 & $1.11 * *$ & $0.35 *$ & -0.98 & $0.62 * *$ \\
\hline 20 & BM 2003-2 X ML 818 & $1.38 *$ & -0.91 & 0.44 & $1.29 * *$ & -0.29 & -0.12 & 0.21 & $1.42 * *$ & $0.33 *$ & $1.45 *$ & $-0.70 * *$ \\
\hline 21 & BM 2003-2 X PUSA0612 & 0.88 & $1.08^{*}$ & 2.09 & $-0.84 * *$ & -0.18 & $-4.10 * *$ & -0.09 & $-1.62 * *$ & $-1.13 * *$ & $-1.70 *$ & $-0.72 * *$ \\
\hline 22 & AKM 4 X IPM 409-4 & 0.70 & $-1.94 * *$ & -1.98 & 0.50 & $0.75 * *$ & $2.33 * *$ & $-1.85 * *$ & $-1.35 * *$ & -0.07 & $1.82 * *$ & $1.13 * *$ \\
\hline 23 & AKM 4 X ML 1299 & $1.70^{*}$ & 0.45 & $5.05 * *$ & -0.05 & $0.53 * *$ & $-1.05^{*}$ & $1.53 * *$ & $1.00 * *$ & -0.15 & 0.74 & $0.50^{*}$ \\
\hline 24 & AKM 4 X MH 2-15 & $1.40^{*}$ & $-1.64 * *$ & $-6.32 * *$ & $1.98 * *$ & 0.02 & $4.51 * *$ & 0.34 & 0.06 & -0.03 & $1.96^{* *}$ & $-1.26 * *$ \\
\hline 25 & AKM 4 XIPM 2-3 & -0.20 & 0.65 & 0.33 & $1.29 * *$ & $-0.93 * *$ & $-2.70 * *$ & 0.06 & 0.09 & -0.10 & $-3.33 * *$ & -0.144 \\
\hline 26 & AKM 4 X ML 2037 & $-3.30 * *$ & $-1.34 * *$ & 1.74 & $-0.87 * *$ & 0.11 & $1.36^{* *}$ & 0.30 & $-0.35 * *$ & -0.08 & 0.76 & $0.387 *$ \\
\hline 27 & AKM 4 X ML 818 & 0.10 & 0.65 & $-3.45 * *$ & -0.31 & -0.25 & 0.07 & -0.43 & 0.16 & -0.06 & $-1.58^{*}$ & -0.09 \\
\hline 28 & AKM 4 X PUSA 0612 & -0.40 & $3.15 * *$ & $4.64 * *$ & $-1.50 * *$ & -0.24 & $-4.55 * *$ & 0.16 & $0.38 * *$ & $0.44 * *$ & -0.37 & $-0.52 * *$ \\
\hline 29 & VAIBHAV X IPM 409-4 & $-2.01 * *$ & 0.70 & $2.520 *$ & $0.89 * *$ & 0.38 & $3.62 * *$ & 0.38 & 0.09 & 0.15 & $2.69 * *$ & $-1.33 * *$ \\
\hline 30 & VAIBHAV X ML 1299 & $-1.51 *$ & -0.40 & $4.48 * *$ & $2.09 * *$ & -0.23 & $2.43 * *$ & 0.41 & 0.09 & -0.18 & $2.06 * *$ & 0.21 \\
\hline 31 & VAIBHAV X MH 2-15 & $1.68 *$ & $-1.50 * *$ & $3.005^{*}$ & -0.06 & $0.45^{*}$ & $-1.94 * *$ & 0.12 & $0.57 * *$ & $0.31 *$ & -0.75 & $1.83 * *$ \\
\hline 32 & VAIBHAV X IPM 2-3 & 0.08 & $-1.70 * *$ & $-2.53 *$ & $-1.25 * *$ & 0.09 & $-3.26 * *$ & $-1.17 * *$ & $-0.31 *$ & $-0.39 * *$ & $-2.54 * *$ & -0.06 \\
\hline 33 & VAIBHAV XML 2037 & $1.48^{*}$ & 0.80 & $-7.72 * *$ & $-2.02 * *$ & -0.20 & $1.60 * *$ & -0.40 & $-0.82 * *$ & $-0.65 * *$ & -0.35 & 0.13 \\
\hline 34 & VAIBHAV X ML 818 & -1.11 & $1.30 * *$ & -0.12 & $0.68 *$ & $-0.62 * *$ & $-1.28 *$ & 0.15 & -0.21 & -0.17 & -1.22 & $-0.77 * *$ \\
\hline \multirow[t]{3}{*}{35} & VAIBHAV X PUSA 0612 & $1.38 *$ & 0.80 & 0.37 & -0.30 & 0.13 & $-1.16^{*}$ & 0.49 & $0.59 * *$ & $0.93 * *$ & 0.11 & -0.01 \\
\hline & SE (+) & 0.62 & 0.45 & 1.14 & 0.26 & 0.19 & 0.48 & 0.34 & 0.12 & 0.13 & 0.62 & 0.18 \\
\hline & CD $5 \%$ & 1.27 & 0.91 & 2.33 & 0.53 & 0.39 & 0.98 & 0.70 & 0.26 & 0.26 & 1.33 & 0.38 \\
\hline
\end{tabular}

$*$ and $* *$ indicates significance at 5 and 1 per cent level respectively 
The cross combination VAIBHAV $x$ PUSA 0612 (0.93) recorded highest significant desirable SCA effect for hundred seed weight.

Similar result has also been reported by Katiyar (2015) and Tiwari and Ramanujan (1974).

In case of protein per cent the cross combination VAIBHAV X MH 2-15 (1.83) observed highest significant desirable SCA effect. These results are with confirmation with the result of Shanthi priya et al., (2012).

The parents showed high GCA can be used for the future hybridization programmes. The gca estimates of lines and testers emphasized the importance of lines AKM 4 and tester IPM 2-3, ML 1299 for their use as a desirable parents for enhancing the yield potential through assembling the favourable genes for yield and yield components.

The crosses which showed high SCA effect could be used for the hybrid development. The high yielding crosses viz., BM 2003-2 X IPM 2-3, VAIBHAV X IPM 409-4, BM 4 X MH 2-15 were found to be the superior for seed yield and yield component and should be further tested across the different environment for their stability performance.

AKM 4 was best combiner for seed yield per plant and other some character like number of pod per cluster, number of pod per plant and negative significant for days to $50 \%$ flowering; ML 1299 for days to maturity, number of pod per plant, seed yield per plant and IPM 2-3 for days to 50\% flowering, days to maturity, number of cluster per plant, number of pod per cluster, number of pod per plant, pod length, seed yield per plant and protein content. Since high gca effect are due to additive and additive $\mathrm{x}$ additive gene action they can be readily exploited in breeding program (Griffing, 1956).

\section{References}

Aher, R. P., Datur D. V. and Sonawane, Y. P., 1999. Combining ability in mungbean. Crop Res., 18:256-260.

Ahuja, S. L. 1980. Diallel analysis in $F_{2}$ generation of mungbean, Thesis Abstract (NAU- Hissar). 6(2): 110-111.

Barad, H. R., Pithia, M. S. and Vachhani, J. H. 2008. Heterosis and combining ability studies for economic traits in mungbean (Vigna radiate (L.)Wilczek). Legume Res., 31.

Choudhary, R. K. 1986. Combining ability for seed yield and its component in mungbean. Crop.Improv., 13(1):95-97.

Dasgupta T., Banik, A. and Das, S. 1998. Combining ability in mungbean. Indian J. Pulses Res., 11(1): 28-32.

Deshmukh, R. B., Manjare, M. R. 1980. Combining ability in mungbean. Legume Res., 3(2): 97-101.

Griffing, B. 1956. Concept of general and specific combining ability in relation to diallel crossing system. Australian J. Biol. Sci, 9:484-493.

Halakunde, I. S., Aher, R. P., Deshmukh, R. B. and Kute, N. S. 1996.Combining ability analysis in greengram. $J$. Maharashtra Agric.Univ.,21(2): 235238.

Jahagirdar, J. E. 2001. Heterosis and combining ability studies for seed yield and yield components in mungbean. Indian j. pulses Res., 14(2): 141-142.

Katiyar, M and Amit Kumar. 2015. Genetics Analysis of yield and its component Traits in Mungbean (Vigna radiata L. Wilczek). Internat. J. of Innovative Res. And Development 4 (2): 119-121.

Kempthorne, O. 1957. An introduction to genetical statistics. John Wiley and Sons, New York.

Khattak, G.S.S., Haq, M.A., Ashraf, M. and Srinives P., 2001. Combining ability in mungbean (Vigna radiata (L)Wilczek) I. 
Agronomic traits. Korean J. Crop Sci., 46(5): 420-423.

Manjare, M. R. 1976. Studies on heterosis and combining ability in $8 \times 8$ diallel cross of mungbean. M. Sc. (Agri.). Thesis Mahatma Phule Krishi Vidyapeeth, Rahuri.

Panse, V.G. and Sukhatme, P. V. 1967. Statistical methods for agricultural work. Indian council of Agric. Res., New Delhi, pp. 167-174.

Sathya, M. and Jayamani, P. 2011. Heterosis and combining ability studies in greengram. J. of Food Legumes 24(4): 282-287.

Shanthi Priya, M., Reddy, K H. P Reddy D. M., and Rupesh Kumar Reddy., 2012. Combining ability studies in greengram. (Vigna radiate (L.) Wilczek). Legume Res., 31(1): 36-39.

Singh M., 2005. Study of combining ability for physiological traits in urdbean (Vignamungo (L.) Hepper). Legume
Res., 28(2):107-110.

Singh, B. B. and Dikshit, H. K. 2003. Combining ability studies for yield and architectural traits in mungbean. (Vigna radiata (L.) Wilczek) Indian J. Genet., 63(4): 351-352.

Sprague, G. F. and Tatum L. A. 1942. General verses specific combining ability in single crosses of corn. $J$. Amer. Soc. Agron.,34: 923-932.

Suresh, S., Jebaraj, S., Juliet Hepziba, S. and Theradimani, M. 2010. Genetic studies in mungbean (Vigna radiata (L.) Wilczek) Electronic $J$. of Plant breeding, 1 (6): 1480-1482.

Tiwari, A. S. and Ramanujan, S. 1974. Partial diallel analysis of combining ability in mungbean.Z. Pflazucht, 73(1): 103-111.

Yadav, P. S. and Lavanya, G. R. 2011. Estimation of combining ability effect in mungbean (Vigna radiata (L.) Wilczek) crosses. Madras Agric. J. 98 (7-9): 213-215.

\section{How to cite this article:}

Surashe, S.M., D.K. Patil and Gite, V.K. 2017. Combining Ability for Yield and Yield Attributes Characters in Greengram (Vigna radiata L. Wilczek). Int.J.Curr.Microbiol.App.Sci. 6(11): 3552-3558. doi: https://doi.org/10.20546/ijcmas.2017.611.416 